\title{
Studying Part-Time in Canada's Universities: A Social Change Perspective
}

\author{
PAUL ANISEF*
}

\begin{abstract}
Part-time university undergraduate students participation in the Canadian postsecondary education system has grown substantially over the past several decades. This growth raises questions concerning the factors influencing students' decisions to enrol full or part-time. The research presented here is based on the 1973-74 and 1983-84 National Postsecondary Student Surveys conducted by Statistics Canada and examines the changing influence of demographic, regional, socioeconomic and financial factors on registration status.

The results indicate: (1) a diminishing impact of regional forces in choosing part-time registration status; (2) a dramatic increase of women in part-time studies (particularly older women); (3) that being married and having dependent children has become significantly less of a barrier for enroling part-time; (4) that students from more educationally advantaged backgrounds were more likely to register full-time in both survey years and the effect of parents' education remained unchanged across the surveys; (5) students that either applied for a government loan or borrowed to finance their studies were more likely to enrol full-time; this pattern was clearer for both sexes in 1983/84 than in 1974/75.

These detailed findings are evaluated in terms of social changes in Canada, particularly with respect to women's increased participation in education and the labor market. While part-time university students constitute a relatively new clientele in higher education, their number and diversity is likely to grow, increasing our need to acquire new and more detailed information.
\end{abstract}

\section{RÉSUMÉ}

L'importance des étudiants universitaires de premier cycle à temps partiel dans le réseau canadien de l'éducation postsecondaire s'est grandement accrue au cours des dernières décennies. Cette croissance soulève des questions quant aux

*Division of Social Science, York University.

Acknowledgement: I wish to thank Frederick D. Ashbury and Michael Skolnik for their comments on an earlier draft of this work and Edmond Ting for developing the logistic regression models employed in this paper. 
facteurs influençant la décision des étudiants de s'inscrire à plein temps ou à temps partiel. La recherche dont il est ici question se fonde sur les enquêtes nationales sur les étudiants du niveau postsecondaire réalisées en 1973-1974 et 1983-1984 par Statistique Canada. Elle étudie l'évolution de l'influence des facteurs démographiques, régionaux, socio-économiques et financiers sur le genre d'inscription.

On a tiré les conclusions suivants. 1) Les facteurs régionaux ont de moins en moins d' influence dans la décision de s' inscrire à temps partiel. 2) Le nombre de femmes (particulièrement de femmes plus âgrées) a fortement augmenté chez les étudiants à temps partiel. 3) Le fait d'être marié(e) et d'avoir des enfants à charge est devenu un obstacle beaucoup moins important à l' inscription à temps partiel. 4) Les étudiants provenant de milieux ayant reçu une meilleure éducation étaient plus susceptibles de s'inscrire à plein temps, dans les deux années d' enquête, et l'influence de l'éducation des parents est demeurée la même d'une enquête à l'autre. 5) Les étudants qui avaient soit demandé un prêt du gouvernement soit contracté un emprunt pour financer leurs études étaient plus susceptibles de s'inscrire à plein temps, et cela se vérifiait davantage en 1983-1984 qu'en 1973-1974, chez les étudiants des deux sexes.

Ces conclusions détaillées sont évaluées sur le plan des changements sociaux au Canada, particulièrement pour ce qui est de la participation accrue des femmes à l'éducation et au marché du travail. Alors que les étudiants universitaires à temps partiel constituent une clientèle relativement nouvelle de l'éducation supérieure, leur nombre et leur diversité continueront vraisemblablement à augmenter, rendant ainsi encore plus grand notre besoin de nouveaux renseignements plus détaillés.

\section{INTRODUCTION}

Canada is experiencing a change from an industrial to a knowledge-based society where many newly created jobs are in knowledge processing, handling and the services sectors. Dramatic, even extraordinary, growth in postsecondary education over the past quarter century reflects or correlates with this transition. Between 1965 and 1985 full-time university and college enrolments multiplied by a factor of 4.10 to $1,120,500$ and expenditures totaled $\$ 9.3$ billion (Watts, 1987).

Another significant development has been the growth in part-time university enrolments in the last two decades, increasing almost 300\%, from 73,000 in 1965 to 285,000 in 1985 (Belanger and Omiecinski, 1985:22). In contrast, total full-time enrolments increased by $179 \%$ during the same time period.

Belanger et al. (1982) has presented an historical review of participation in part-time university studies from 1939 to 1979 . This review shows that women outnumbered men in the part-time student population in the 1940s and continue to do so. By $1984,62 \%$ of the part-time undergraduate population were comprised by women. Furthermore, the part-time student population has broadened in age and 
continues to age. In $1971,44 \%$ of part-time students were 30 years of age or over; by 1984 this proportion increased to $64 \%$.

Bertrand concludes that the 'traditional' university student (that is, one who directly enters from secondary school) will no longer be in the majority by the 1990s (1982). Rather, a different population - one that tends to be older and female and whose periods of study extend over a number of years and often across different disciplines - is entering Canadian universities in greater numbers. ${ }^{1}$ Campbell (1984) urges university administrators to shift their focus on preoccupation with traditional students and formulate policies that will better serve the needs of a 'new majority' of adult learners. The Levy-Coughlin Partnership (1981) in a survey of some 4000 part-time university students develops a picture of this new majority. They are well educated, career-oriented individuals with a persistent commitment to education. About half of those surveyed had aspirations to professional or graduate school education and most were generally satisfied with their educational experiences. Perhaps the most significant barrier perceived was the availability of time to pursue their education because of work and personal commitments.

This literature review shows that Canadian research studies pertaining to parttime undergraduate university students have been almost exclusively descriptive the exception being Robert Pike's study of part-time studies in Ontario (1978). The increased numbers of part-time, older, female students raise a number of important issues and researchable questions. For instance, what sociological factors help us understand the decision to study on a part-time basis? Has the influence of these factors altered over the decades? What socioeconomic and demographic changes in Canada have influenced the decision to study part-time? In 1965 , for example, $26 \%$ of the total university population was composed by part-time students. Twenty years later this increased to 38\% (Belanger and Omiecinski, 1986:23). While some of this increase can be attributed to a population composition shift in the $25-44$ age group $(26.7 \%$ in 1961 and $32.2 \%$ in 1986), other social changes, particularly increases in the participation by women in postsecondary education and the labour market provide more convincing arguments (COPS Bulletin, 1987:2). ${ }^{2}$

\section{MODEL AND DATA}

The conceptualization of the choice process leading to matriculation as a full or part-time student was developed in a previous paper and builds on Hassler's (1985) work. Hassler:

... visualize the course of selection as being very much like a funnel. At the start, each high school student considers a wide variety of postsecondary school options. These options become increasingly more specific and detailed until we move to the mouth of the funnel, when the matriculation decision is made. At the beginning or predisposition phase, a number of factors including students socioeconomic background, attitudes and attributes, the influence of significant others, high school 
characteristics, and academic ability are deemed to be important. The middle or search phase of the college choice model includes such factors as college communication strategies (e.g. campus visits, written information), perceived quality of postsecondary institutions and information-gathering (e.g. net cost of attending various postsecondary institutions). In the third phase or choice stage, students narrow their selection to one of several institutions. (Anisef, McAdam and Ting, 1987:7)

The decision-making model employed in this analysis assumes that at least a portion of university students make a conscious choice (whether explicit or implicit) between attending university full or part-time. This choice must be relevant to a sufficiently large number of students for changes in the mix of socio-demographic and economic variables to be associated with changes in the over-all balance between full-time and part-time students.

While decision-making model(s) are insensitive to more general social changes that subsequently influence postsecondary choice, their repeated use serves to identify important changes in the effects of variables. More global or general social changes (e.g. increases in female labor force participation) can then be introduced and discussed. After identifying temporal changes in the effects of selected characteristics on registration status, more general social changes (e.g. increased female labor force participation) will be considered.

Data analysed in this paper derive from two nation-wide Post-secondary Student surveys conducted by Statistics Canada for the Secretary of State. The 1974-75 survey was conducted in February, 1975 and the total sample consisted of 66,880 students in university and 35,925 community college students. The 1983-84 survey was conducted during February and March 1984. Of a total sample of $63,948,54,302$ usable responses were obtained, for a gross response rate of 85 per cent. ${ }^{3}$ Respondents in both survey years were stratified by province, type of institution, registration status and level of study. Within each stratum, there was proportional allocation by sex and field of study. A variety of data collection techniques were employed in both surveys. These included mail out questionnaires, telephone reminders and telephone interviews.

Both surveys experienced a number of problems with coverage of the target population, mainly undercoverage due to non-responding institutions, partial reporting, and timing. One major institution did not participate in the 1974-75 survey while 24 university-level institutions failed to respond in the 1984-84 survey. ${ }^{4}$ Most of the 24 non-responding universities were small, the exceptions being Mount Saint-Vincent, Concordia, York, Winnipeg, and Lethbridge. Of these, Concordia and York are most important since both have enrolments in excess of 25,000 and attract large numbers of part-time students and higher than average proportions of students from less privileged backgrounds. The estimated enrolment of the non-responding universities represented $10.3 \%$ of total estimated university-level enrolment (Porter and Jasmin, 1987:51-54). Thus, while nonresponding institutions introduce some bias, we anticipate that the general patterns revealed in this analysis would not significantly alter had students from these institutions been included in the sample. 
A second, more severe limitation concerns student non-registrants and particularly part-time students in 1983-84. The sampling frame was derived from registration information in the Fall semester while data collection occurred in the Spring. A comparison of USIS information and the 1983/84 survey sample revealed that about $24 \%$ of part-time students were no longer registered when the survey was actually conducted. Since these 'missing' students are likely to differ from those registered in both terms, it is difficult for us to generalize findings to all participating students in Canada.

A third limitation pertains to the sorts of variables in the postsecondary student surveys that can be employed to empirically test Hassler's choice model. While information regarding the influence of significant others, high school characteristics and academic performance and the contact of students with postsecondary institutions was simply not gathered other important variables are available. These variables (see Appendix) include: sex and age; marital status and presence of dependent children; parent's highest level of education completed; whether respondents applied for government loans or borrowed money to finance their studies and respondent's region of study. Ample evidence for the relevance of these variables to part-time university study is provided in a number of works (Anisef, 1987; Anisef and Ting, 1985; Pike and McIntosh, 1978).

\section{METHODS}

To ascertain the effect of a characteristic on registration status while controlling for other characteristics, logistic regression models are employed (Fox, 1984). The estimated coefficients in the logistic models express the linear effects of independent variables on the logarithm of the odds-ratio, that is, the odds of registering part-time rather than full-time. It should be noted that positive coefficients indicate higher probabilities of registering part-time. Since it is difficult to conceptualize in terms of log-odds, the analysis transforms the coefficients into the change in probability resulting from a unit increment in an independent variable. This change in probability is computed by the formula:

$$
\text { 스 } \mathrm{p}=(\exp (\mathrm{Li} /[1+\exp (\mathrm{Li})]-\exp (\mathrm{LO}) /[1+\exp (\mathrm{LO})]) \times 100 \%
$$

where exp denotes the exponentiation to the power of the constant $\mathrm{e}$, and LO - $\operatorname{Ln}[\mathrm{p} /(1-\mathrm{p})]$, the logit of the odds-ratio at the sample mean on the dependent variable, p. Ln denotes the natural logarithm. $\mathrm{Li}=\mathrm{LO}+\mathrm{Bj}$ represents the logit after a unit increment in the independent, where $\mathrm{Bj}$ is the estimated coefficient (Petersen, 1985).

In order not to bias the parameter estimates or the estimates of standard errors, the logistic analyses were based on unweighted data. Table 1 presents the descriptive statistics of variables employing the logistic analysis by sex and year. Standard deviations are computed for the variable AGE only. All the others are zero-one dummy-coded variables and, thus, are not interpretable in terms of standard deviations. 
TABLE 1. MEANS OE VARIABLES IN THE LOGIT MODELS OF REGISTRATION STATUS BY SEX AND YEAR (UNDERGRADUATES)

\begin{tabular}{|c|c|c|c|c|c|c|}
\hline \multirow[b]{2}{*}{ VARIABLES } & \multirow[b]{2}{*}{ MALE } & \multicolumn{2}{|c|}{$1974-75$} & \multicolumn{2}{|c|}{$1983-84$} & \multirow[b]{2}{*}{$\begin{array}{c}\text { ALL } \\
1983-84 \\
\end{array}$} \\
\hline & & FEMALE & $\begin{array}{c}\text { ALL } \\
1974-75\end{array}$ & MALE & FEMALE & \\
\hline STATUS (a) & .108 & .178 & .140 & .270 & .391 & .336 \\
\hline$A G E(b)$ & $\begin{array}{l}22.80 \\
14.31\end{array}$ & $\begin{array}{r}23.58 \\
6.53\end{array}$ & $\begin{array}{r}23.10 \\
5.46\end{array}$ & $\begin{array}{r}25.32 \\
7.26\end{array}$ & $\begin{array}{r}27.17 \\
9.02\end{array}$ & $\begin{array}{r}26.32 \\
8.31)\end{array}$ \\
\hline MARRIED & .171 & .183 & .177 & .224 & .288 & .259 \\
\hline CHILD & .077 & .105 & .090 & .156 & .237 & .200 \\
\hline LOAN & .523 & .470 & .498 & .474 & .439 & .455 \\
\hline BORROW & .537 & .460 & .502 & .504 & .447 & .473 \\
\hline \multicolumn{7}{|c|}{ PARENTS EDUCATION: } \\
\hline $\begin{array}{l}\text { SECONDARY/ } \\
\text { TRADE }\end{array}$ & .295 & .283 & .290 & .315 & .297 & .305 \\
\hline $\begin{array}{l}\text { SOME POST- } \\
\text { SECONDARY }\end{array}$ & .175 & .206 & .189 & .179 & .192 & .186 \\
\hline BACHELOR'S & .126 & .129 & .127 & .143 & .138 & .140 \\
\hline POST GRAD. & .081 & .096 & .087 & .109 & .093 & .100 \\
\hline \multicolumn{7}{|l|}{ REGIONS: } \\
\hline PRAIRIES & .342 & .334 & .338 & .281 & .292 & .287 \\
\hline ONTARIO & .143 & .150 & .146 & .151 & .160 & .160 \\
\hline QUEBEC & .121 & .121 & .121 & .122 & .111 & .116 \\
\hline ATLANTIC & .271 & .287 & .278 & .330 & .324 & .327 \\
\hline \multicolumn{7}{|l|}{ SEX } \\
\hline & -- & -- & .461 & $\cdots$ & --- & .542 \\
\hline$N(c):$ & 8181 & 6984 & & 6008 & 7115 & \\
\hline YEAR: & .464 & & & & & \\
\hline
\end{tabular}

NOTE: ALL VARIABLES ARE UNWEIGHTED.

a Part time students are coded 1 , and full-time students, 0 .

$b$ The standard deviations of AGE are in parantheses

c The sub-sample sizes include only respondents with no missing cases on the variables in the logit models.

The specification of models is based on the availability of variables in both survey years. Since one major interest concerns the temporal changes in the effects of independent variables, logistic models are fitted to the data separately for the two survey years. Since it is also important to distinguish the differential impact of independent variables separately for males and females, the logistic models are fitted for each sex within each year. These separate analyses result in four identical logistic models as shown in Table's 2 and 3. 
TABLE 2. ESTIMATED COEFFICIENTS AND PREDICTED CHANGES IN PERCENTAGE $(=\chi)$ FOR THE LOGIT MODELS AND REGISTRATION STATUS (UNDERGRADUATES), 1974-75. (a)

\begin{tabular}{|c|c|c|c|c|c|c|}
\hline \multirow[b]{2}{*}{ VARIABLES } & \multirow[b]{2}{*}{ ESTINATES } & \multicolumn{2}{|l|}{ MALES } & \multirow[b]{2}{*}{ ESTIMATES } & \multicolumn{2}{|c|}{ FEMALES } \\
\hline & & p & $=2$. & & $p$ & $=\%$ \\
\hline INTERCEPT & -7.925 & .0001 & --- & -5.938 & .0001 & -- \\
\hline$A G E$ & .213 & .0001 & 2.23 & .150 & .0001 & 2.30 \\
\hline MARRIED & 1.178 & .0001 & 17.42 & 1.428 & .0001 & 29.65 \\
\hline CHILD & .534 & .0001 & 6.32 & .702 & .0001 & 12.61 \\
\hline LOAN & -.241 & .097 & -2.11 & -.195 & .18 & -2.68 \\
\hline BORROW & -.229 & .11 & -2.02 & -.334 & .021 & -4.38 \\
\hline $\begin{array}{l}\text { PARENT'S } \\
\text { EDUCATION (b }\end{array}$ & b) --- & .014 & --- & --- & $<.001$ & --- \\
\hline $\begin{array}{l}\text { SECONDARY } \\
\text { TRADES }\end{array}$ & -.076 & .48 & -0.71 & -.138 & .18 & -1.93 \\
\hline $\begin{array}{l}\text { SOME POST } \\
\text { SECONDARY - }\end{array}$ & -.333 & .014 & -2.81 & -.28 & .014 & -3.80 \\
\hline BACHELOR'S- & -.346 & .031 & -2.91 & -.605 & .0001 & -7.23 \\
\hline POST GRAD. - & -.489 & .017 & -3.89 & -.982 & .0001 & $-10 \cdot 30$ \\
\hline REGIONS (c) & $-\cdots$ & $<.001$ & --- & $-\cdots-$ & $<.001$ & $-\cdots$ \\
\hline PRAIRIES & .466 & .0059 & 5.37 & .518 & .0018 & 8.86 \\
\hline ONTARIO & .742 & .0001 & 9.47 & .426 & .024 & 7.10 \\
\hline QUEBEC & 1.053 & .0001 & 14.96 & 1.126 & .0001 & 22.24 \\
\hline ATLANTIC & .708 & .0001 & 8.93 & .631 & .0002 & 11.13 \\
\hline$-2 \times \underset{\log L i}{\operatorname{like} 1}$ & $\begin{array}{l}\text { ikelihood ( } \\
\text { lihood-rati }\end{array}$ & $\begin{array}{l}\text { cercept) } \\
\text { chi-square }\end{array}$ & $e^{11341.3}$ & dif) & $\begin{array}{c}9681.9 \\
5539.0 \quad 124\end{array}$ & dif ) \\
\hline
\end{tabular}

a The estimated coefficients and changes in percentage represent the likelihood that one chose part-time as opposed to full-time study.

$b$ The reference category is no formal education or less than secondary education.

c The reference category is in the province of British Columbia.

The four models are then combined into a single model with first- and second-order interactions for sex, year and each of the other independent variables. ${ }^{5}$ Analyses are performed employing this combined model to identify temporal changes in and sex differentials relative to the impact of other independent variables, that is, the interaction effects. Note that the principle of marginality is observed in all the non-additive models; that is, if an interaction term is present, the corresponding main effects are also included (Fox, 1984). 
TABLE 3. ESTIMATED COEFFICIENTS AND PREDICTED CHANGES IN PERCENTAGES $(=x)$ FOR THE LOGIT MODELS OF REGISTRATION STATUS (UNDERGRADUATES), 1983-84. (a)

\begin{tabular}{|c|c|c|c|c|c|c|}
\hline \multirow[b]{2}{*}{ VARIABLES } & \multicolumn{2}{|c|}{ MALES } & \multirow[b]{2}{*}{$=\%$} & \multirow[b]{2}{*}{ ESTIMATES } & \multirow{2}{*}{$\begin{array}{l}\text { FEMALES } \\
\mathrm{P}\end{array}$} & \multirow[b]{2}{*}{$=\%$} \\
\hline & ESTIMATES & $p$ & & & & \\
\hline INTERCEPT & -6.355 & .0001 & $-\cdots$ & -5.790 & .0001 & --- \\
\hline AGE & .212 & .0001 & 4.38 & .202 & .0001 & 4.90 \\
\hline MARRIED & .819 & .0001 & 18.62 & 1.374 & .0001 & 32.63 \\
\hline CHILD & .279 & .038 & 5.84 & .013 & .91 & 6.81 \\
\hline LOAN & -.417 & .0005 & -7.40 & -.308 & .0044 & -7.04 \\
\hline BORROW & -.356 & .0025 & -6.42 & -.589 & .0001 & -12.83 \\
\hline & \multicolumn{3}{|c|}{ PARENT'S } & $\cdots-$ & $<.001$ & --- \\
\hline $\begin{array}{l}\text { SECONDARY/ } \\
\text { TRADES }\end{array}$ & .057 & .57 & 1.14 & -.041 & .66 & -.97 \\
\hline $\begin{array}{l}\text { SOME POST } \\
\text { SECONDARY }\end{array}$ & -.191 & .11 & -3.60 & -.127 & .22 & -2.98 \\
\hline BACHELORS & -.568 & .0001 & -9.67 & -.389 & .0011 & -8.78 \\
\hline POST GRAD. & -.313 & .029 & -5.71 & -.783 & .0001 & -16.41 \\
\hline REGIONS (c) & $\cdots \cdots$ & .16 & $\cdots-$ & $\cdots \cdot$ & .033 & $\cdots$ \\
\hline PRAIRIES & -.018 & .809 & -.365 & -.028 & .82 & -.67 \\
\hline ONTARIO & .208 & .16 & 4.29 & .267 & .048 & 6.51 \\
\hline QUEBEC & .228 & .13 & 4.72 & .248 & .085 & 6.04 \\
\hline ATLANTIC & .017 & .90 & .34 & .091 & .46 & 2.19 \\
\hline $\begin{array}{l}2 \times \text { log likel } \\
\text { likelihood ra }\end{array}$ & $\begin{array}{l}\text { hood (interce } \\
\text { io chi-square }\end{array}$ & & & $\begin{array}{l}8328.7 \\
3853.6\end{array}$ & $\begin{array}{l}9863.5 \\
5315.1\end{array}$ & \\
\hline
\end{tabular}

a The estimated coefficents and changes in percentage represent the likelihood that one chooses part-time as opposed to full-time study.

b The reference category is no formal education or less than secondary education.

c The reference category is the province of British Columbia.

\section{FINDINGS}

\section{Environmental and demographic characteristics}

The effect of a student's region of study ${ }^{6}$ for 1974-75 is clearly supported by the estimated coefficients shown in Table 2 . Overall regional effects are statistically significant at $\mathrm{p}<.001$ for both sexes. Particularly noteworthy was the far greater likelihood of male and female undergraduates from Quebec choosing part-time 
status than British Columbian undergraduates. By way of illustration, male Quebec undergraduates were $15 \%$ more likely and female Quebec undergraduates $22 \%$ more likely than their British Columbian peers to select part-time registration status.

The impact of a student's region of study on choice of registration status in 1983-84 is statistically significant for females $(p=.033)$ but not for males. A comparison of estimated coefficients in Table's 2 and 3 generally indicates that a sharp reduction of influence by region on registration status for both sexes has occurred between 1974-75 and 1983-84. Age played a modest but statistically significant role for male and female undergraduates $(p=.0001)$ in its influence on registration status. Older male students were more likely to study part-time in 1974-75. Results are virtually identical for female undergraduates.

The effect of age on registration status in 1983-84 was similar to that identified for 1974-75. Older male and female undergraduates were more likely to enrol part-time in 1983-84 $(\mathrm{p}=.0001)$.

Marital status, of all student characteristics in the regression model (and particularly for females), had the most powerful impact on determining registration status. This effect was statistically significant at $\mathrm{p}=.0001$. Married female undergraduates were $29.6 \%$ more likely than single female undergraduates to opt for part-time registration status. Married male undergraduates were $17 \%$ more likely than single male undergraduates to enrol part-time. It can be seen that marriage, with its associated family obligations, was one factor that strongly predisposed undergraduates to study part-time in 1974-75.

The family obligations associated with being married exerted effects on male and female undergraduates in 1983-84 similar to those in 1974-75. Married males were $19 \%$ more likely and married females $33 \%$ more likely to enrol part-time in 1983-84 ( $p=.0001)$. Female undergraduates with children were $13 \%$ more likely to enrol part-time while male undergraduates with similar obligations were $6 \%$ more likely to study part-time.

The presence of dependent children also had strong effects on registration status for both male and female undergraduates $(p=.001)$ in 1974-75. While the influence of having dependent children on registration status was similar for male undergraduates across the survey years the situation altered for female undergraduates. Male undergraduates in 1983-84 were 6\% more likely to enrol part-time $(p=.038)$. For female undergraduates the relationship is not statistically significant $(p=.91)$. It would appear that women in the eighties do not identify having dependent children as a rationale for choosing part-time over full-time registration. Part of the explanation may relate to improvements in daycare and the increased commitment by women to participate fully in higher education. While this may be so for many women, the reader should recall that the postsecondary surveys may not adequately reflect the situation of all part-time students in Canada, given the large number of part-time undergraduates that dropped out before the surveys were conducted. 


\section{Socioeconomic Status ${ }^{7}$}

The overall impact of parents' education on registration status was statistically significant for male $(p=.014)$ and female $(p=.001)$ undergraduates in 1974-75. Recall that no formal education or less than secondary education is the reference category employed in the analysis. Table 2 reveals, for male and female undergraduates alike, that the probability of enrolling full-time increases as parental educational attainment increases. By way of illustration, female undergraduates whose parents have a secondary school/trades education are $2 \%$ more likely than peers whose parents have no formal education or less than secondary to opt for full-time registration status. In contrast, female undergraduates whose parents are post-graduates are $10 \%$ more likely to enrol full-time. The pattern for male undergraduates is similar but less marked.

The overall effect of parent's education or registration status for male and female undergraduates also proved statistically significant $(\mathrm{p}<.001)$ in 1983-84. Students from a more advantaged educational background (particularly if parents had a postgraduate education) were more likely to enrol full-time in undergraduate studies. For example, female undergraduates whose parents have a postgraduate education were $16 \%$ more likely to enrol full-time than counterparts whose parents had no schooling or less than secondary. When female undergraduates whose parents have a secondary/trades education is examined the probability of enrolling full-time is reduced to less than $1 \%$.

\section{Economic Factors}

Male and female undergraduates who applied for a government loan to support their university studies were somewhat less likely to enrol part-time in 1974-75. These effects were not statistically significant.

While the effect of applying for a government loan was not statistically significant for either male or female undergraduates in 1974-75, such was not the case in 1983-84. For both sexes, an application for a loan increased the probability of enrolling full-time ( $p=.0005$ for males and $p=.0044$ for females). Thus, male and female undergraduates were approximately $7 \%$ more likely to enrol on a full rather than part-time basis if they had applied for a government loan. ${ }^{8}$

When we turn to examining the impact of borrowing to finance university studies a similar pattern emerges. Those male and female undergraduates who borrowed were less likely to enrol part-time. While the effect of borrowing is not statistically significant for males it is for females $(p=.021)$. Thus, female undergraduates that borrow are $4 \%$ less likely to enrol part-time.

While the effect of borrowing to finance university studies on registration status proved statistically significant only for females in 1974-75, this effect was significant for both sexes $(p=.0025$ for males and $p=.0001$ for females) in 1983-84. By way of illustration, male undergraduates who borrowed were $6 \%$ more likely while female undergraduates were $13 \%$ more likely to enrol full-time. 
TABLE 4. ESTIMATED COEFFICIENTS OF FIRST-ORDER YEAR INTERACTIONS IN LOGIT MODELS OF REGISTRATION STATUS BY SEX (UNDERGRADUATES)

\begin{tabular}{|c|c|c|c|c|}
\hline \multirow[b]{2}{*}{ VARIABLES } & \multicolumn{2}{|l|}{ MALES } & \multicolumn{2}{|c|}{ FEMALES } \\
\hline & ESTIMATES & $p$ & ESTIMATES & P \\
\hline AGE $X$ YEAR & -.001 & .94 & .052 & .0001 \\
\hline MARRIED X YEAR & -.360 & .023 & -.053 & .69 \\
\hline CHILD X YEAR & -.255 & .18 & -.688 & .0001 \\
\hline LOAN X YEAR & -.176 & .35 & -.112 & .53 \\
\hline BORROW X YEAR & -.127 & .50 & -.254 & .16 \\
\hline $\begin{array}{l}\text { PARENT'S EDUC } \\
X \text { YEAR }\end{array}$ & --- & .44 & $\cdots$ & .75 \\
\hline $\begin{array}{l}\text { SECONDARY } \\
\text { TRADES }\end{array}$ & .133 & .36 & .097 & .48 \\
\hline $\begin{array}{l}\text { SOME POST } \\
\text { SECONDARY }\end{array}$ & .142 & .43 & .158 & .31 \\
\hline BACHELORS & -.222 & .29 & .215 & .27 \\
\hline POST GRAD & .176 & .48 & .199 & .41 \\
\hline REGIONS X YEAR & $\cdots$ & .0081 & --- & $<.001$ \\
\hline PRAIRIES & -.485 & .024 & .546 & $.007 \varepsilon$ \\
\hline ONTARIO & -.533 & .025 & -.160 & .49 \\
\hline QUEBEC & -.825 & .0005 & -.878 & .0001 \\
\hline ATLANTIC & .691 & .0017 & -.540 & .010 \\
\hline
\end{tabular}

These findings illustrate a commonsense linkage between registration status, total educational costs and the need to either borrow or apply for loans. Full-time study is more costly than part-time study and substantially increases the need to borrow. It should also be noted that success at borrowing may enable students to register full-time while failure may require students to enrol part-time.

\section{Interactions}

There was a greater probability of older women than older men enrolling part-time in 1974-75 ( $p=.0001)$ but not in 1983-84. Married women were more likely than married men to enrol on a part-time basis in both survey years though this tendency was more pronounced in 1983-84. Finally, an interaction effect between sex and parent's education (at the postgraduate level) was detected in both survey years. Female undergraduates whose parents attained a postgraduate degree proved more likely than their male counterparts to enrol part-time. 


\section{Temporal changes}

This part of the analysis offers us the opportunity to identify changes in the effects of variables in the regression models for males and females separately between 1974-75 and 1983-84.

\section{Environmental and demographic characteristics}

Estimated coefficients in Table 4 clearly demonstrate that student's region of study had substantially diminished in its effect on registration status from 1974-75 to 1983-84. This applies equally to male $(p=.008)$ and female undergraduates $(\mathrm{p}<.001)$. This should not be interpreted to mean that region does not count. Only that its impact relative to other variables in our regression models has weakened in influencing the choice of registration status. Female undergraduates that live permanently in Ontario form the exception to this general pattern. Although the estimated coefficient indicates a small decline in effect (relative to British Columbia) the result is not statistically significant.

While the effect of age declined slightly among males, this decline is not statistically significant. Among females the impact of age on choosing to study part-time actually increased and this increase is statistically significant $(p=.00001)$. A separate examination of second-order interactions shows that the sex difference in impact of age is statistically significant over time while the differential impact of age for the two sexes has diminished. Why has this happened? At the university level, the female component increased dramatically from $21 \%$ in 1955 to $48 \%$ in 1985 (National Forum, 1987). From 1970 to 1985 the number of women in Canadian universities more than doubled and the increase in enrolments during the 1970 's was caused almost exclusively by the increased participation of women, particularly those over the age 24 attending as part-time students (CAUT, Forum Notes, 1987). While part-time studies offer new opportunities for all Canadians this is increasingly perceived by women over 30 as an important strategy for reshaping their life course.

Among undergraduate males, marriage decreased in its effect on enrolling part-time from 1974-75 to 1983-84. This finding is statistically significant $(p=.023)$. Among females, the decline in the effect of marriage was far more modest and not statistically significant $(p=.69)$. For all undergraduates but particularly for males higher education in the 1980 s is perceived in terms of its relation to career preparation and upgrading. This constitutes a shift in emphasis compared with the seventies. Married men increasingly recognize the need to upgrade their skill levels and credentials if they are to gain promotion or simply maintain job security. Given these developments over the last decade or so, marriage per se among men has had diminishing importance to influencing the choice of part-time registration status. While these same developments have influenced women, traditional role relationships between men and women have altered, albeit slowly. That changes are taking place is supported by the significant 
decline in effect on part-time registration status among women of having dependent children $(\mathrm{p}=.0001)$. The decline among males was more modest and not statistically significant. While these temporal changes are positive they should not be cause for celebration. As mentioned earlier in this section, many part-time students dropped out before either the 1974-75 or 1983-84 surveys were conducted. More importantly, we know very little about those women (and men) who decided against enrolling either part- or full-time due to parential obligations and responsibilities.

\section{Socioeconomic status}

In all cases except among males whose parents had a bachelor's level of education, there was no increased effect of parents' education on part-time registration status from 1974-75 to 1983-84. These effects are neither statistically significant for males $(p=.44)$ nor females $(p=.75)$.

\section{Economic factors}

These effects of either obtaining a government loan or borrowing to finance their university declined in importance for male and female undergraduates. However, such declines were not statistically significant.

\section{CONCLUSIONS AND IMPLICATIONS}

The analysis of temporal changes in enrolling part-time among undergraduate students provide a number of significant insights that can be related to the choice model presented earlier in this paper. While the decision to register on a full or part-time basis is significantly influenced by regional, demographic, socioeconomic and economic factors, dynamic social change (e.g. inflation, recession, demographic) can, in a relatively short period of time, influence the decisionmaking process that results in postsecondary choices. Thus, while regional forces played a substantial role in choosing part-time registration status in 1983-84 their impact was more muted in comparison to 1974-75.

Given the provincial range in studying part-time across Canada in 1983-84 (from $22 \%$ in Nova Scotia to $52 \%$ in Quebec), uncovering the dimensions that make region a potent factor remains a critical problem for social scientists. As Belanger and Pedersen argue, national studies should systematically consider important regional differences. Neglecting such differences may be misleading (1973:102).

A particularly significant temporal change concerns the dramatic increase of women in part-time enrolment - over $300 \%$ between 1965 and 1985. The corresponding increase for men was 158\% (Belanger and Omiecinski, 1987:24). This means that women have become an even more dominant group in part-time studies, making up about $59 \%$ of enrolments. 
This part-time enrolment surge is indicative of even more fundamental changes with respect to the status of women and sex roles over the past $40-50$ years. In considering the post-secondary system as a whole, the proportion of female students shifted from $36 \%$ in 1955 to $49 \%$ in 1985 . At the university level the shift was more dramatic, from $22 \%$ in 1955 to $48 \%$ in 1985 (National Forum, 1987:2). However, to place this change in perspective the majority of Canadian women and men $(71 \%$ and $68 \%$ respectively in 1985 ) have no more than a high school education. Furthermore, about twice as many men as women possess trade certificates and diplomas (Canadian Congress for Learning Opportunities for Women, 1986: 19-20).

Equally dramatic has been the increased participation by women, 15-64, in the Canadian labor force, from $21 \%$ in 1941 to $55 \%$ in 1985 . In the past decade or so, the labor force participation of women with young children (3 years of age or younger) has grown most significantly, from $31 \%$ in 1976 to $56 \%$ in 1985 (Canadian Congress for Learning Opportunities for Women, 1986:65). Oppenheimer (in Romaniuc, 1987:71) sees this as reflecting an "economic squeeze" where a larger number of babyboomers entered a labor force in a time of economic slowdown and rising inflation. While modelling their aspirations for high standards of living on those of their parents, rising inflation and unemployment meant that consumption aspirations outstripped the economic resources for achieving them - usually the husband's income. Rather than suffer from relative economic deprivation, women in the U.S. (and I would suggest women in Canada) have entered the labor force in ever increasing numbers.

Increases in postsecondary and labour force participation by women parallel a more fundamental shift from a traditional division of sex roles toward a greater integration of women into the economic system. Romaniuc cites Thornton and Freedman who found that "American women had made a tremendous shift toward more egalitarian sex roles between 1962 and 1977" (1987:65-66). Changes in general principles have been occurring with substantial increases in a nontraditional orientation among women. Accompanying these global changes is a decline in fertility rates, with fewer people marrying (or those that marry, marrying later in life) and many more divorcing (Romaniuc, 1987:59). Thus, the number of married part-time undergraduates declined from $61.2 \%$ in 1974-75 to $56.9 \%$ in $1983-84$. The proportion either separated or divorced increased from $5.9 \%$ to $8.5 \%$. While it makes sense that an increasing number of divorced or separated persons are viewing a university education as a strategy for adapting to changed circumstances, reshaping lives and forging new career directions, information to test this hypothesis is not available in the postsecondary student surveys.

I suggest also that the data provide indirect evidence for a role incompatibility or conflict theory, particularly with regard to working mothers who enrol as part-time university students. While general changes in sex roles and attitudes have clearly occurred, most housework chores and child-rearing responsibilities are assumed by working wives (Romaniuc, 1987:68). 
Adult learners (and particularly women) often encounter indifference to their problems on Canadian campuses (Campbell, 1984:49). A study of mature students at Atkinson College in Ontario led the authors to conclude that "our analysis points to fundamental gender differences in the transition to university. Such differences should be addressed by universities concerned with amelioration or easing the problems encountered by part-time adult learners who must frequently juggle personal, work and family responsibilities" (Anisef and Ting, 1985:183). As I indicated earlier, the comparison of the 1983-84 survey sample and USIS information shows that a significant minority of part-time students (about 24\%) were no longer registered when the survey was conducted. It is likely that students that persisted, did so in part because they were able to resolve their 'role incompatibility' problems. Without being able to trace the university careers of part-time students from the time they first register in programs, the role incompatibility hypothesis must remain at the level of plausible speculation. Lorne Tepperman and Charles Jones (1988:2-3) suggest the unfolding of a trend whereby, between the present and 2025 , the adult female life cycle will become increasingly individualized. This individualization refers to an increase in the number of statuses, an increased movement among statuses over time and an increasing variation in the predictors of status among women. If this is so, then the negative consequences of role incompatibility may be part of this unfolding. As women adjust, the stress resulting from role incompatibility should diminish. Should universities recognize that future clientele, in the face of a diminishing 18-24 age cohort, will consist of older, part-time students, they may respond by becoming more accommodating and institutionally less rigid. This too, should help reduce the stress associated with role incompatibility.

Both postsecondary surveys show that greater proportions of part-time students are drawn from disadvantaged backgrounds than are full-time students. And yet over half of all part-time students in 1983-84 already held postsecondary qualifications. About $28 \%$ had completed no more than a secondary level education. These observations suggest that the 'second-chance' hypothesis applies to only a minority of part-time students. (Porter, 1986:26). For the majority, part-time study is a reaction to a changing technological society and the resulting need for lifelong learning skills upgrading. But what are the outcomes (e.g. for the labor market) of part-time study? While teachers constituted the major clientele for part-time studies in the early 1970s, this clientele has since declined. In 1983-84 only $8.7 \%$ of male and $12.8 \%$ of female part-time undergraduates selected Education as their major field of study. The comparable figures for 1974-75 were $12.8 \%$ for male and $27.1 \%$ for females. Bertrand (1985:122-123) in her review of accessibility research in Quebec (the province having the largest proportion of part-time students) indicates strong concern by educators that a limited range of short, less prestigious programs of study are available to part-time students. These programs lead not to degrees but certificates. Furthermore, there is a particularly high incidence of part-time study among Francophones and women. Without additional educational and occupational outcome data it is difficult to evaluate the 
more favorable 'second chance' or democratization perspective in contrast with the more critical or cynical perspective suggested by Bertrand.

Given the greying of the Canadian population (by the year 2030 there should be twice as many Canadians over age 65), the focus on personal growth, the individual and life-long learning, the expansion and need for adult education programs seems assured. While part-time university students constitute a relatively new clientele in Canadian higher education their number and diversity will likely grow. And so will our need to acquire more detailed information regarding the experiences of various sub-groups of part-time university students.

\section{REFERENCES}

Anisef, P. (1987). Part-time University Students in Canada: An Analysis of the 1974-75 and 1983 Postsecondary Student Surveys. Unpublished report, Education Sector, Secretary of State.

Anisef, P., McAdam, D., and Ting, E. (1987). Who Goes to University or College in Canada: An Analysis of the 1983-84 Postsecondary Student Survey. Unpublished paper, York University.

Anisef, P., and Ting, E. (1985). Adult University Leamers in Ontario: an Analysis of their Problem Experiences, Transitions to Work, The Institute for Social and Economic Research, University of Manitoba.

Belanger, P. W. and Pedersen, E. (1973). Projects des étudiants quèbecois. Sociologie et sociétiés, $5(1), 91 \cdot 110$.

Belanger, R. and Omiecinski, T. (1986). Part-time University Enrolment. Canadian Social Trends, Statistics Canada, Cat. 11-008E.

Belanger, R. and Lynd, D. and Mouelhi, M. (1982). Part-time Degree Students: Tomorrow's Majority? Ottawa: Statistics Canada.

Bertrand, Marie-Andree. (1972). To Whom is Postsecondary Education Available? Postsecondary Education Issues in the 1980s. Proceedings of the CMEC Conference on Postsecondary Education. Toronto.

Campbell, Duncan D: (1984). The New Majority: Adult Learning in the University. The University of Alberta Press, Edmonton.

Canadian Association of University Teachers. (1987). Accessibility, Forum Notes.

Canadian Congress for Learning Opportunities for Women. (1986). Decade of Promise, An Assessment of Women's Status in Education, Training and Employment, 1976-1985. Avebury Research \& Consulting Ltd.

COPS Bulletin. (1987). Major Findings from the Canadian Occupational Projection System, Demographics, Employment and Immigration Canada.

Fox, J. (1984). Linear Statistical Models and Related Methods. New York: John Wiley and Sons.

Hassler, D. (1985). A Research Review of Student College Choice, presented at the American Society for the Study of Higher Education. Chicago Illinois.

Levy-Coughlin Partnership. (1981). Program Availability and Student Needs in Part-time Studies at Ontario Universities. Ministry of Colleges and Universities, Ontario.

National Forum on Postsecondary Education. (1987). A Statistical Portrait of Higher Education in Canada. Saskatoon.

Oppenheimer, V.K. (1980). Work and the Family: A Study in Social Demography, Academic Press, Harcourt Brace Javanovich.

Petersen, T. (1985). A Comment on Presenting Results from Logit and Probit Analysis. American Sociological Review, 50, pp. 130-131.

Pike, R. and McIntosh, N.E. (1978). Innovation in access to higher education, Urban Dahllof, New York: Intemational Council for Educational Development, Interbook, Inc. 
Porter, M. (1986). Accessibility and Student Finance. Canadian Sociological and Anthropological Association Meetings, Winnipeg, Manitoba.

Porter, M. and Jasmin, G. (1987). A Profile of Post-Secondary Students in Canada. Department of the Society of State and Statistics Canada.

Romaniuc, A. (1987). Fertility in Canada: From Baby-boom to Baby-bust. Demography Division, Statistics Canada, Cat. 91-524E, Minister of Supply and Services.

Tepperman, L. and Jones, C. (1988). The individualization of adult women's lives. The Review of Demography and li's Implications for Economic and Social Policy, Update Four, Spring.

Watts, R. L. (1987). The Challenges and Opportunities Facing Post-Secondary Education in Canada. The Forum Papers, National Forum on Post-Secondary Education, The Institute for Research on Public Policy.

\section{APPENDIX}

\section{Variables employed in this analysis}

AGE

MARRIED

CHILD

LOAN

BORROW

REGIONS

PARENT'S

EDUC

SEX

YEAR

REGISTRATION

STATUS
Age of respondents in years. Since the 1974-75 data on age are grouped in 5 year intervals, the midpoints are used.

Married respondents are coded as 1 and all others as 0.

Respondents are coded 1 for those who had dependent children and 0 for those who had no dependent children.

Those who had applied for government loans are assigned the value of 1 and those who had not, 0 .

Respondents are coded 1 if they had borrowed money to finance their university education and 0 if otherwise.

Recoded from the respondents' region of study, the five regions are: British Columbia, the Prairie provinces, Ontario, Quebec, and the Atlantic provinces. These regions are coded into four dummy variables, with British Columbia assigned as the reference category.

Parent's (or guardian's) education is defined as the highest level of education completed by the more academically qualified parent. It is coded into five levels and represented by four dummy variables. The five levels are: (1) less than secondary school, (2) completed secondary or trades school, (3) some postsecondary college or university, and nursing or teachers college, (4) Bachelor's degree, and (5) postgraduate degree - Master's, Ph.D., or degree in law, medicine or dentistry. The "less than secondary school" level is employed as the reference category. The values of 1 and 0 are assigned to females and males, respectively.

Respondents in the 1974-75 survey are coded 0 and those in the 1983-84 survey, 1.

Part-time respondents are coded 1 , and full-time respondents, 0 . 


\section{NOTES}

1 At York University, for example, students are described not in terms of their year of study but in terms of course credits.

2 Two-thirds of part-time university students were between the ages of 25-44 in both 1975 and 1985 .

3 While the national postsecondary surveys contain information on part-time graduate students, only data pertaining to undergraduates are analysed in this paper. Of the total part-time university student population, more than $77 \%$ in $1974-75$ and $86 \%$ in $1983-84$ were at the undergraduate level.

4 Weighted figures do not account for institutions not participating in the two surveys.

5 An interaction effect occurs when two or more variables work together to produce a phenomenon (e.g. registration status). Interaction is present when the effect of one independent variable on the dependent variable actually depends on the attributes of one or more other independent variables.

6 About $93 \%$ of students studying in a region also count that region as their permanent place of residence. While the data demonstrates the strong influence of 'region', the factor(s) associated with region (e.g. unemployment rate, relationship of universities and colleges) are not incorporated into the analysis of registration status.

7 One would anticipate that the economic status of student's parents would prove an important factor in determining registration status. Income and occupational information pertaining to parents were not requested when students' age equalled or exceeded 30 . Since a large percentage of part-time university students are $\mathbf{3 0}$ years of age or older this precluded the use of income and occupation in this analysis.

8 Causation, in this instance, may run in the opposite direction. Once students decide to enrol they may then seek a government loan. Much more is required for full-time than part-time attendance. Also, it has been traditionally easier to secure government loans as a full-time rather than as a part-time student. 